Article

\title{
Protective Effect of Cashew Gum (Anacardium occidentale L.) on 5-Fluorouracil-Induced Intestinal Mucositis
}

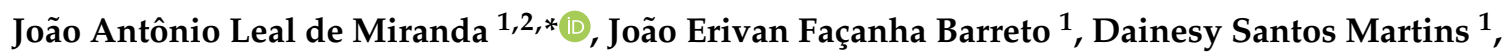 \\ Paulo Vitor de Souza Pimentel ${ }^{1}$, Deiziane Viana da Silva Costa ${ }^{1}$, Reyca Rodrigues e Silva ${ }^{2}$, \\ Luan Kelves Miranda de Souza ${ }^{2}$, Camila Nayane de Carvalho Lima ${ }^{3}$, Jefferson Almeida Rocha ${ }^{4}$, \\ Ana Paula Fragoso de Freitas ${ }^{1}$, Durcilene Alves da Silva ${ }^{2}$ (D), Ariel Gustavo Scafuri ${ }^{1}$, \\ Renata Ferreira de Carvalho Leitão ${ }^{1}$, Gerly Anne de Castro Brito ${ }^{1}$, \\ Jand Venes Rolim Medeiros ${ }^{2}(1)$ and Gilberto Santos Cerqueira ${ }^{1,2}$ \\ 1 Department of Morphology, Faculty of Medicine, Federal University of Ceará, s/n Delmiro de Farias Street, \\ Porangabuçu Campus, Fortaleza 60416-030, Brazil; erivanfacanha@yahoo.com.br (J.E.F.B.); \\ dainy.santos@gmail.com (D.S.M.); paulo_vitordesouza@hotmail.com (P.V.d.S.P.); \\ deiziane2009@gmail.com (D.V.d.S.C.); paulinhaff2@hotmail.com (A.P.F.d.F.); urologia@gmail.com (A.G.S.); \\ leitao_renata@yahoo.com.br (R.F.d.C.L.); gerlybrito@hotmail.com (G.A.d.C.B.); \\ giufarmacia@hotmail.com (G.S.C.) \\ 2 Biotechnology and Biodiversity Center Research, BIOTEC, Federal University of Piauí, Parnaíba, Piauí \\ 64202-020, Brazil; reyca_14@hotmail.com (R.R.e.S.); luankelves11@gmail.com (L.K.M.d.S.); \\ durcileneas@yahoo.com.br (D.A.d.S.); jandvenes@ufpi.edu.br (J.V.R.M.) \\ 3 Nucleus of Research and Development of Medications (NPDM), Federal University of Ceará, Coronel Nunes \\ de Melo Street, 100, Fortaleza 60430-275, Brazil; camilacarvalhoenf@yahoo.com.br \\ 4 Research Group in Natural Sciences and Biotechnology, Federal University of Maranhão, s/n Avenue Aurila \\ Maria Santos Barros de Sousa, Frei Alberto Beretta, Grajaú-MA 65940-000, Brazil; jeffersonkalel@hotmail.com \\ * Correspondence: joaoantonio@ufpi.edu.br; Tel.: +55-85-3366-8492
}

Received: 31 December 2018; Accepted: 15 March 2019; Published: 3 April 2019

check for updates

\begin{abstract}
Intestinal mucositis is a common complication associated with 5-fluorouracil (5-FU), a chemotherapeutic agent used for cancer treatment. Cashew gum (CG) has been reported as a potent anti-inflammatory agent. In the present study, we aimed to evaluate the effect of CG extracted from the exudate of Anacardium occidentale L. on experimental intestinal mucositis induced by 5-FU. Swiss mice were randomly divided into seven groups: Saline, 5-FU, CG 30, CG 60, CG 90, Celecoxib (CLX), and CLX + CG 90 groups. The weight of mice was measured daily. After treatment, the animals were euthanized and segments of the small intestine were collected to evaluate histopathological alterations (morphometric analysis), levels of malondialdehyde (MDA), myeloperoxidase (MPO), and glutathione (GSH), and immunohistochemical analysis of interleukin 1 beta (IL-1 $\beta$ ) and cyclooxygenase-2 (COX-2). 5 -FU induced intense weight loss and reduction in villus height compared to the saline group. CG 90 prevented 5-FU-induced histopathological changes and decreased oxidative stress through decrease of MDA levels and increase of GSH concentration. CG attenuated inflammatory process by decreasing MPO activity, intestinal mastocytosis, and COX-2 expression. Our findings suggest that CG at a concentration of $90 \mathrm{mg} / \mathrm{kg}$ reverses the effects of 5-FU-induced intestinal mucositis.
\end{abstract}

Keywords: intestinal mucositis; heteropolysaccharide; 5-fluorouracil; inflammation

\section{Introduction}

Cancer, a complex disease characterized by uncontrolled cell growth, is one of the main causes of morbidity and mortality in both developed and developing countries [1-3]. Chemotherapeutic agents 
can controlled the dissemination of several tumors and improve the quality of life in most patients with cancer. Currently, 5-fluorouracil (5-FU) is one of the major chemotherapeutic agents used for the treatment of cancer. 5-FU is a fluorinated pyrimidine with antimetabolite activity. However, it can cause side effects such as nausea, vomiting, diarrhea, myelosuppression, and intestinal mucositis [4-9].

Mucositis is initiated by basal cell lesions in the gastrointestinal tract, resulting in mucosal damage, intense inflammatory reaction, and consequent ulceration. It affects around $40 \%$ of patients treated with chemotherapeutic agents $[10,11]$. Intestinal mucositis can increase the risk of bacterial translocation and sepsis, thus impairing the continuity of anticancer treatment.

Owing to the lack of efficacious therapeutic tools for the treatment of intestinal mucositis, new alternative therapeutics that can reduce the side effects of 5-FU, without impairing cancer treatment, have been investigated.

Cashew gum (CG), a high-molecular weight complex heteropolysaccharide, is obtained from the exudate of cashew tree (Anacardium occidentale L.) through condensation of a large number of aldose and ketose molecules [12,13]. Its anti-inflammatory, antiulcerogenic, and antidiarrheal activity have been reported in previous studies [14-17]. In this study, we investigated the effect of CG on 5-FU-induced experimental intestinal mucositis. In addition, we evaluated its effect on inflammatory process and oxidative stress, as well as the involvement of cyclooxygenase 2 (COX-2).

\section{Results}

\subsection{Weight Analysis}

As expected, from the second day, all mice subjected to 5-FU-induced intestinal mucositis presented progressive weight loss, which was significant compared to the saline group $(p<0.05)$. Notably, only CG 60 pretreatment prevented weight loss induced by 5-FU $(p<0.05)$. CG 30 and CG 90 were unable to reverse 5-FU-induced weight loss (Figure 1).

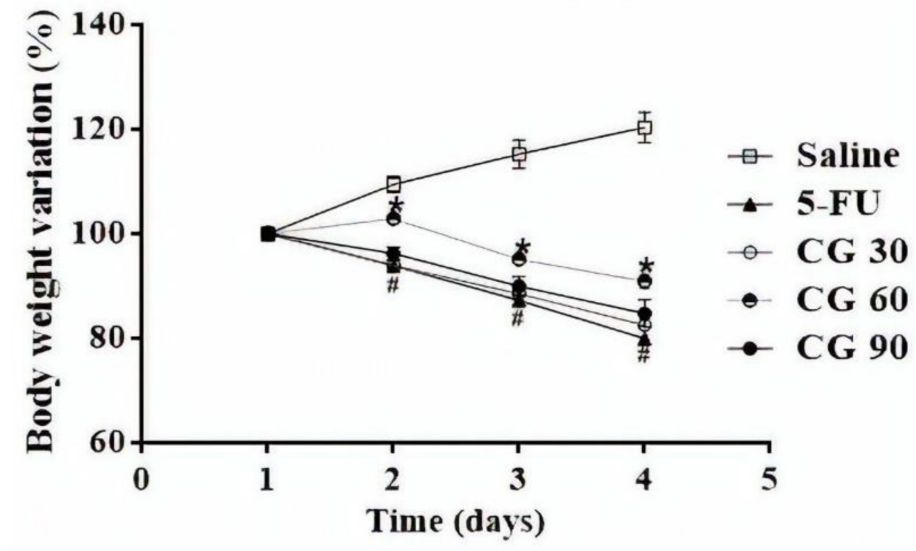

Figure 1. Body weight variation in mice subjected to intestinal mucositis (5-FU, $450 \mathrm{mg} / \mathrm{kg}$, ip, single dose) and treated with CG (30, 60 and $90 \mathrm{mg} / \mathrm{kg}$ for 4 days). The results are expressed as the mean \pm SEM of the weight evaluation percentage of the initial weight, of a minimum of 6 animals per group. Two-way ANOVA followed by the Tukey's test were used for the statistical analysis, where \# $p<0.05$ vs. saline and * $p<0.05$ vs. 5 -FU.

\subsection{Histopathological and Morphometric Analysis}

The 5-FU group showed intense inflammatory cell infiltration, disruption of intestinal mucosal architecture, and a significant reduction in villus height, crypt depth, and villus/crypt ratio compared to saline group $(p<0.05)$ (Figure $2 \mathrm{~B}$ ). Notably, all doses of CG attenuated the effects induced by 5-FU $(p<0.05)$ (Figure 2C-H). Moreover, a significant increase in histopathological scores was found in 5-FU group $(p<0.05)$ compared to the saline group (Table 1). CG 90 pretreatment decreased 
the histopathological scores compared to the 5-FU group $(p<0.05)$. However, CG 30 and CG 60 pretreatment did not reduce histopathological scores.
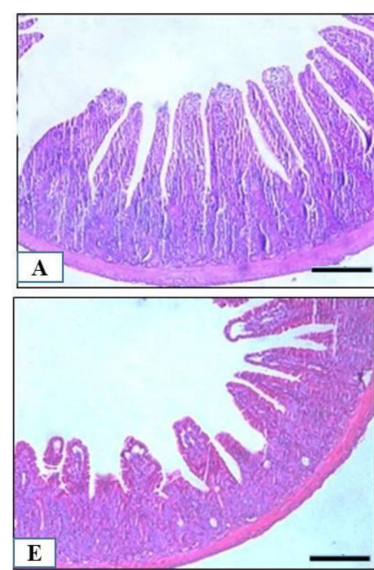
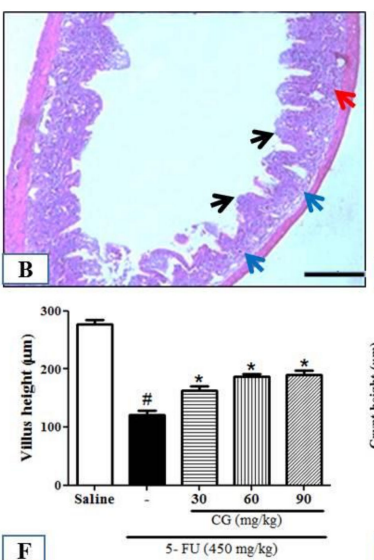
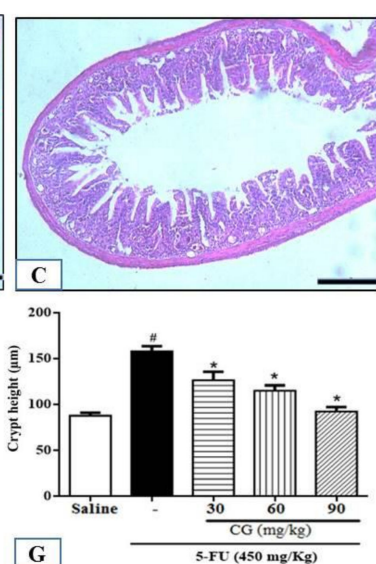
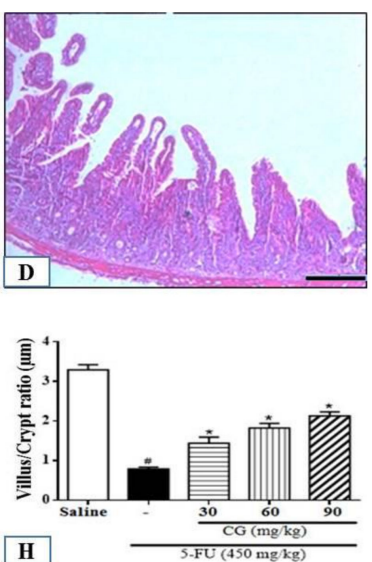

Figure 2. Histopathological analysis. (A) Saline; (B) 5-FU; (C) CG 30; (D) CG 60; (E) CG 90. 5 FU induced inflammatory cell infiltrate (red arrow), decreased intestinal villi (black arrow), loss of intestinal crypt architecture (blue arrow). Pretreatment with CG (30, 60 and $90 \mathrm{mg} / \mathrm{kg}$ ) decreased the inflammatory infiltrate and prevented the shortening of the villi (F), increased crypt depth $(\mathbf{G})$ and decreased villus/crypt ratio (H), with greater reversion of the 5-FU effect in the CG $90+5$-FU group. All panels were obtained on the $100 \mu \mathrm{m}$ scale $(\times 200)$. Values were expressed as mean \pm SEM. One-way ANOVA followed by the Tukey's test were used for the statistical analysis was used, where \# $p<0.05$ vs. saline group and * $p<0.05$ vs. group 5-FU.

Table 1. Histopathological scores of mice subjected to 5-FU-induced intestinal mucositis and pretreated with CG.

\begin{tabular}{cc}
\hline Groups & Scores \\
\hline Saline & $0(0-0)$ \\
5-FU & $2(1-3) \#$ \\
CG 30 & $3(3-3)$ \\
CG 60 & $1(1-2)$ \\
CG 90 & $1(0-1)^{*}$ \\
\hline
\end{tabular}

Values were expressed as median, where $\# p<0.05 \mathrm{vs}$. saline and ${ }^{*} p<0.05 \mathrm{vs}$. 5 -FU ( $n=6 /$ group). The data was analyzed by the Kruskal-Wallis test followed by the Dunns multiple comparisons test.

\subsection{Leukocyte Count}

Analysis of leukocyte count in blood showed a significant decrease $(p<0.05)$ in the number of total leukocytes in 5-FU group compared to that in the saline group. In contrast, CG pretreatment reduced 5-FU-induced leukopenia $(p<0.05)$ (Figure 3A). 

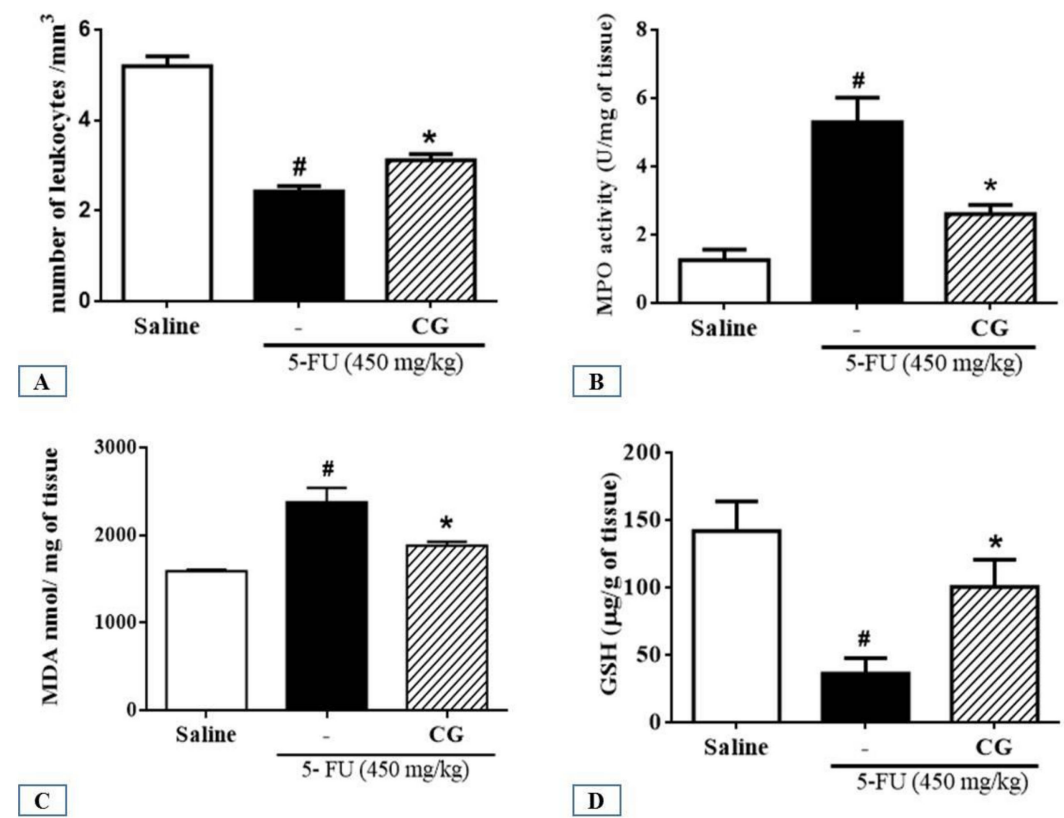

Figure 3. (A) Total leukocyte count; (B) Activity of myeloperoxidase (MPO); (C) Level of malondialdehyde (MDA); (D) concentration of glutathione (GSH). Values were presented as mean \pm SEM. For the statistical analysis, one-way ANOVA followed by Tukey's test was used, where \# $p<0.05$ vs. saline group and * $p<0.05$ vs. group 5-FU.

\subsection{Myeloperoxidase Assay (MPO)}

To investigate the effects of CG pretreatment on neutrophil recruitment in 5-FU-induced intestinal mucositis, we determined the activity of myeloperoxidase (MPO), a neutrophil marker. The 5-FU group presented a significant increase in MPO levels in the duodenum compared to the saline group $(p<0.05)$. CG $(90 \mathrm{mg} / \mathrm{kg})$ pretreatment decreased MPO levels in the duodenum of mice subjected to 5 -FU-induced intestinal mucositis $(p<0.05)$, which in turn decreased polymorphonuclear leukocyte infiltration (Figure 3B).

\subsection{Malondialdehyde (MDA) and Glutathione (GSH) Levels}

To investigate the effect of CG pretreatment on 5-FU-induced oxidative stress in the duodenum, MDA and GSH levels (end products of oxidative stress) were evaluated. We found that 5-FU elevated MDA levels in the duodenum compared to the saline group (Figure 3C). CG (90 mg/kg) pretreatment reduced MDA levels compared to the 5-FU group $(p<0.05)$, thereby reducing 5 -FU-induced oxidative stress (Figure 3C). Animals treated with 5-FU showed a significant $(p<0.05)$ decrease in GSH levels compared to the saline group. In contrast, CG $(90 \mathrm{mg} / \mathrm{kg})$ increased GSH levels compared to the 5- FU group $(p<0.05)$ (Figure 3D).

\subsection{Mast Cell Concentration Analysis}

To evaluate the effect of CG pretreatment on 5-FU-induced mastocytosis, the number of mast cells in the duodenum was measured. 5-FU (Figure 4B) increased the number of mast cells per field in the duodenum compared to the saline group (Figure 4A) $(p<0.05)$. CG $(90 \mathrm{mg} / \mathrm{kg}$ ) pretreatment (Figure $4 \mathrm{C}$ ) decreased the number of mast cells compared to the 5-FU group $(p<0.05)$ (Figure 4D). 

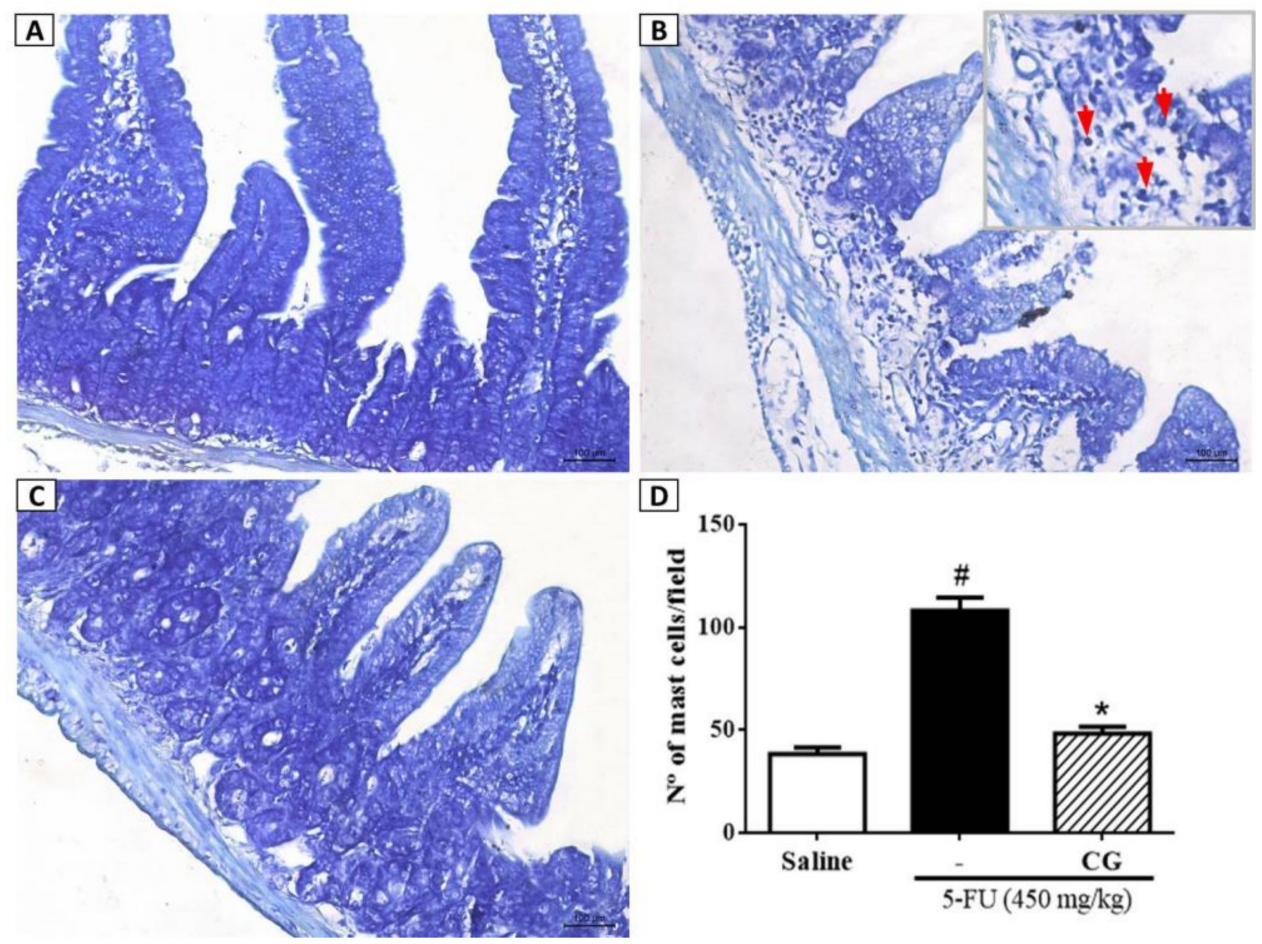

Figure 4. Mast cell counts in the duodenum samples. In (B) demonstrates that 5-FU promoted increased mast cell counts (red arrows) when compared to saline group (A). CG 90 (C) reversed the 5-FU-induced mastocytosis. All the panels were obtained at $\times 400$ magnification. (D) Values were presented as mean \pm SEM of the number of mast cells per field. For the statistical analysis, tone-way ANOVA followed by Tukey's test was used, where \# $p<0.05$ vs. saline group and * $p<0.05$ vs. group 5 -FU.

\subsection{Effect of CG on Cyclooxygenase-2 Pathway in Histopathological and Morphometric Analyses}

To investigate whether the effects of CG on reduction of 5-FU-induced intestinal injury, oxidative stress, and inflammation are mediated by cyclooxygenase-2 (COX-2) pathway, we blocked COX-2 by injecting celecoxib (CLX) in the presence or absence of CG in mice subjected to 5-FU-induced intestinal mucositis. Pretreatment with COX-2 blocker (CLX) (Figure 5D), as well as pretreatment with the combination of CLX and CG (90 mg/kg) (Figure 5E) prevented 5-FU-induced shortening of villus, cellular vacuolization, infiltration of inflammatory cells, edema, and loss of cellular architecture (Figure 5B).

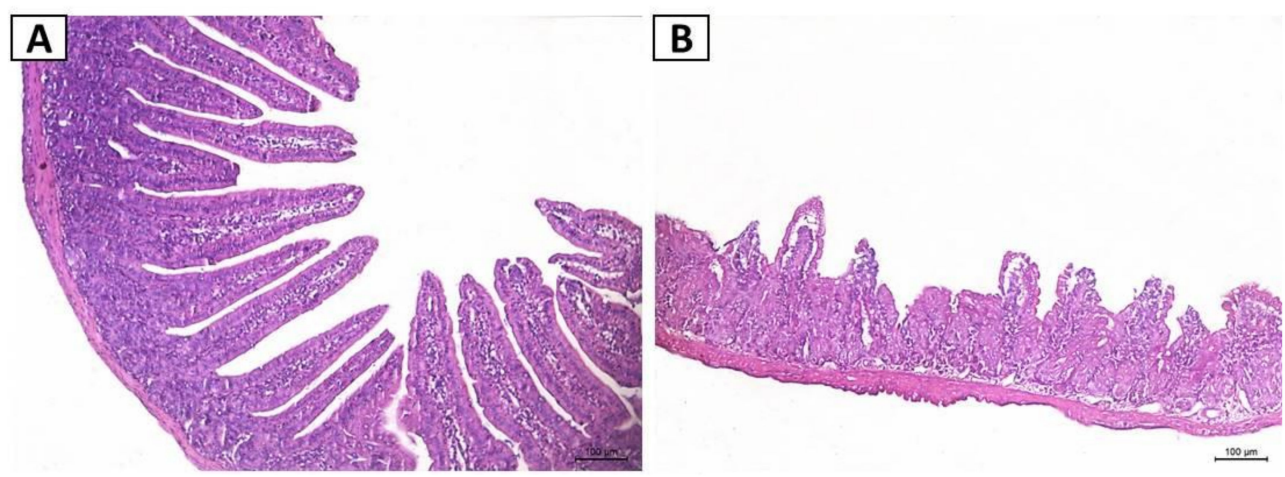

Figure 5. Cont. 

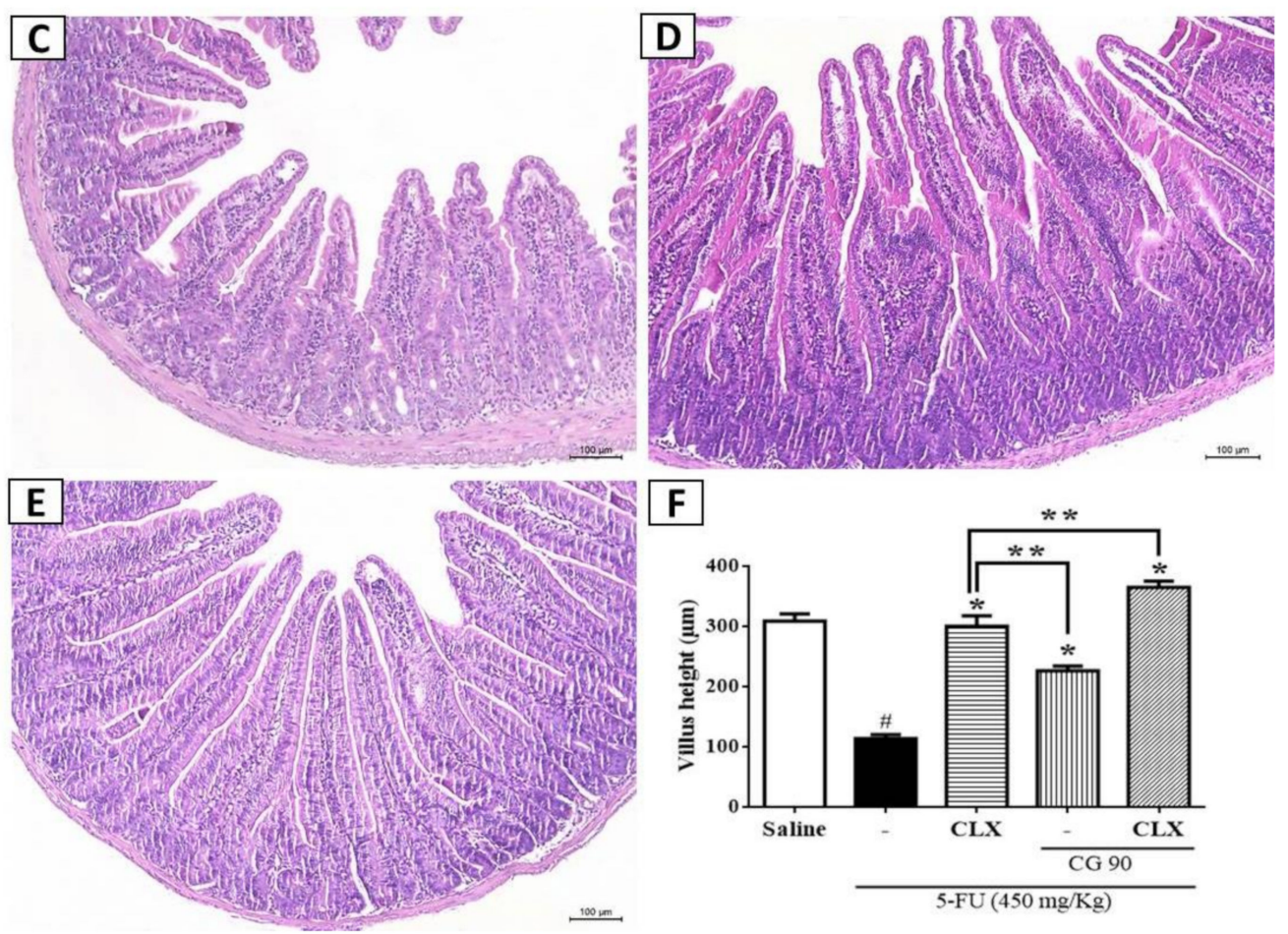

Figure 5. Effect of GC on the cyclooxygenase-2 pathway (COX-2) in histopathological and morphometric. The histopathological analysis represented by the groups (A) Saline; (B) 5-FU; (C) CG 90; (D) Celecoxib (CLX); (E) CLX and CG 90, as well as morphometric analysis of villus height (F) showed that 5-FU caused a decrease in villi and loss of cellular architecture when compared to the saline group. C, D, and E reversed the effect of 5-FU. All panels were obtained at $\times 200$ magnification. Values were expressed as mean \pm SEM for villi height in $\mu \mathrm{m}$. For statistical analysis, one-way ANOVA followed by Tukey's test was used, where \# $p<0.05$ vs. saline group, ${ }^{*} p<0.05$ vs. group $5-\mathrm{FU},{ }^{* *} p<0.05$ vs. group CLX.

CLX pretreatment decreased 5-FU-induced villus shortening $(p<0.05)$. In addition, pretreatment with the combination of CLX and CG $(90 \mathrm{mg} / \mathrm{kg})$ reverted villus shortening induced by $5-\mathrm{FU}(p<0.05)$. Moreover, the combination of CLX and CG $(90 \mathrm{mg} / \mathrm{kg}$ ) (Figure 5F) showed a greater effect on the recovery of duodenal villus in mice subjected to $5-\mathrm{FU}$-induced intestinal mucositis than pretreatment with CG 90 (Figure 5C) or CLX alone (Figure 5C) $(p<0.05)$.

\subsection{Immunohistochemistry for the Detection of COX-2 and IL-1 $\beta$}

We investigated the effects of CG $(90 \mathrm{mg} / \mathrm{kg})$ in the presence or absence of CLX on COX-2 and IL-1 $\beta$ expression during 5-FU-induced intestinal mucositis through immunohistochemical analysis. 5-FU promoted intense immunostaining of COX-2 (Figure 6C) and IL-1 $\beta$ (Figure 6D) in the duodenal mucosa compared to the saline group (Figure $6 \mathrm{~A}, \mathrm{~B}, \mathrm{~K}, \mathrm{~L}, p<0.05$ ). As shown in Figure $6 \mathrm{E}, \mathrm{F}$ CG $(90 \mathrm{mg} / \mathrm{kg})$ pretreatment decreased immunostaining for COX-2 and IL-1 $\beta$, respectively, compared to 5 -FU group (Figure $6 \mathrm{~K}, \mathrm{~L}, p<0.05$ ). Similarly, CLX alone (Figure $6 \mathrm{G}, \mathrm{H}$ ) or the combination of CLX and CG $(90 \mathrm{mg} / \mathrm{kg}$ ) (Figure 6I,J) decreased cell immunostaining forproinflammatory molecules in mice subjected to 5-FU-induced intestinal mucositis compared to the 5-FU group (Figure 6K,L, $p<0.05$ ). Intense immunostaining was evidenced for the 5-FU lesion group, on the lamina followed by mild mucosal immunostaining, also was observed an absence of labeling in the epithelial cells. 

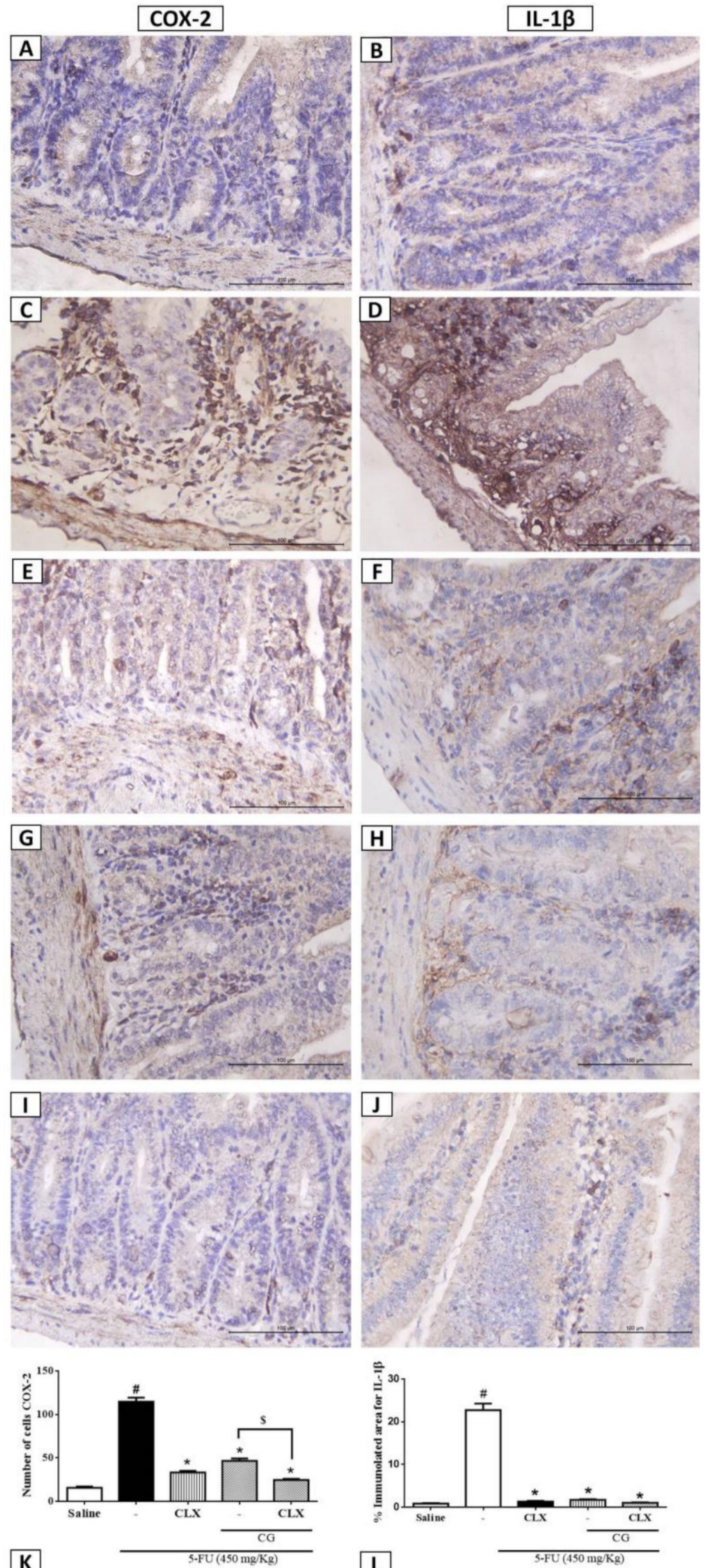

Figure 6. Immunohistochemistry analysis for COX-2 and IL-1 $\beta$. (A,B) Saline; (C,D) 5-FU; (E,F) CLX; $(\mathbf{G}, \mathbf{H})$ CG 90; (I,J) CLX + CG 90. (K) a number of cells immunolabelled for cox-2. (L) \% immunolabelled for IL-1 $\beta$. Values were expressed as mean \pm SEM. For statistical analysis, one-way ANOVA followed by Tukey's test was used, where \# $p<0.05$ vs. saline group, ${ }^{*} p<0.05$ vs. group 5 -FU, $\$ p<0.05$ vs. group CLX. 


\section{Discussion}

In the present study, we evaluated the effects of CG on intestinal mucositis induced by 5-FU and found that CG reversed the effects of 5-FU-induced intestinal mucositis at a concentration of $90 \mathrm{mg} / \mathrm{kg}$. With the continuous expanded use of medicinal plants for the prevention and treatment of different pathologies worldwide, there has been increasing interest in the discovery of natural products with pharmacological effects. In Brazil, many herbal extracts are used in folk medicine to treat various digestive disorders, and several studies have documented the benefits of Brazilian plants in the prevention of gastrointestinal lesions $[18,19]$.

A previous study reported that the extract of Spondias pinnata, belonging to the family Anacardiaceae, decreased histological severity scores and intestinal inflammation, and altered the mucosal architecture after chemotherapy. This indicated that $S$. pinnata extract could be an important pharmacological agent in promoting healing of damaged intestine after chemotherapy [20]. A. occidentale L. has been reported to possess diverse pharmacological properties. Its bark, leaves, and bark oil are used in anti-inflammatory and astringent preparations for the treatment of diarrhea [21]. Previous studies using the extracts of cashew tree bark have reported hypoglycemic [22,23], antioxidant and anti-inflammatory [24], antimicrobial [25], antihypertensive [26], and anticancer effects. It also showed beneficial effects in the treatment of gastritis, diarrhea, and wounds [22,27]. The anti-inflammatory activities and wound healing potential of cashew nuts have also been reported [28].

Weight loss is considered one of the common side effects of 5-FU chemotherapy. Therefore, body mass measure is one of the daily evaluated parameters to confirm the model of intestinal mucositis induced by 5 -FU. Similar to our results, previous studies showed a decrease in body weight of animals after 5-FU-induced intestinal mucositis [29-31]. In this study, we showed that CG 60mg/kg decreased 5-FU-induced weight loss in mice, instead of the other CG doses which the loss weight was irreversible. Studies with probiotics and olmesartan showed that doses of these drugs were considered effective in reversing the harmful effects promoted by chemotherapy in mucositis model, after evaluation of histopathological parameters and inflammatory markers, however they were not effective in reverse weight loss as presented in ours studies [32,33].

Previous studies reported that 5-FU promoted decrease and vacuolization of intestinal villi, cryptic necrosis, infiltration of inflammatory cells, loss of cell architecture, and a decrease in villus/crypt ratio [34-37]. These findings are consistent with those of the present study. In addition, we found that CG at a concentration of $90 \mathrm{mg} / \mathrm{kg}$ was able to reduce the harmful effects of 5-FU on the duodenal mucosa. The anti-inflammatory effect of CG has been reported in skin lesions [15]. Araújo et al. [17] reported that 90 and $60 \mathrm{mg} / \mathrm{kg}$ of CG were effective in the treatment of acute inflammatory diarrhea. Similarly, $90 \mathrm{mg} / \mathrm{kg}$ was the best treatment concentration to prevent histopathological changes in 5-FU-induced intestinal mucositis.

Mucositis and myelosuppression are the main adverse effects related to 5-FU treatment $[7,9,38]$. In the present study, we showed that CG $(90 \mathrm{mg} / \mathrm{kg})$ attenuated leukopenia, the decrease in a number of total leukocytes, induced by 5-FU. Soares et al. [39] and Quaresma [40] demonstrated leukopenia in mice following a single administration of $5-\mathrm{FU}(450 \mathrm{mg} / \mathrm{kg})$.

The ulcerative phase of mucositis is characterized by loss of epithelial integrity of the mucosa, which facilitates a propitious environment for the invasion of bacteria. In addition, leucopenia may potentialize this process, resulting in bacteremia or sepsis [11,41,42]. We suggested that CG can be fundamental in preventing potential generalized bacterial infections during 5-FU treatment because it attenuated 5-FU-induced leukopenia. However, further investigations are needed to confirm this.

CG 90 prevented a 5-FU-induced increase in MPO levels in the duodenum. Similar to the present study, Bastos et al. [43], Justino et al. [44], Ávila et al. [45], Al-Asmari et al. [46], and Carvalho et al. [30] showed an increase in MPO activity after induction of intestinal mucositis by 5-FU. MPO has been used as a quantitative marker of neutrophil infiltration into various organs, including the gastrointestinal tract.

We showed that CG exerted antioxidant effects against intestinal mucositis by increasing GSH levels and decreasing MDA levels in the duodenum of mice subjected to 5-FU-induced intestinal 
mucositis. This finding is in agreement with the result of a previous study demonstrating that CG formulations exerted an antioxidant effect by decreasing MDA levels [47].

Our findings showed that CG reversed 5-FU-induced mastocytosis (increase in a number of mast cells) in the duodenum, indicating potent anti-inflammatory effects of CG in mice with 5-FU-induced intestinal mucositis. Previous studies have shown intense mastocytosis during intestinal mucositis induced by chemotherapeutics in mice $[46,48]$. The role of mast cells in the gastrointestinal tract is paradoxical, as their function depends on the mediators released and receptors activated. Mast cells contribute to intestinal homeostasis through immune protection, regulation of architecture and permeability of the epithelial barrier, and mucosal tissue remodeling through stimulation of fibroblast growth [49]. However, they are considered critical in the pathogenesis of inflammatory processes such as mucositis, because their overexpression consequently leads to amplification of inflammatory response caused by the selective release of mediators [50,51]. Besides exacerbation of inflammation, mastocytosis in the gastrointestinal tract has been reported to culminate in alteration of architecture and impairment of the gastrointestinal barrier, such as villus enlargement and changes in crypt size in the small intestine [52,53].

In the present study, we evaluated the effect of CG on COX-2 pathway by pretreating mice subjected to intestinal mucositis with a combination of CLX (a COX-2 blocker) and CG (90 mg/kg). In addition, we investigated whether the protective effect of CG on morphometric and histopathological changes induced by 5-FU was related to COX-2 inhibition. We found that the combination of CLX and CG $(90 \mathrm{mg} / \mathrm{kg})$ completely reverted 5-FU-induced decrease in villi, cryptic necrosis, inflammatory cell infiltration, and loss of cellular architecture in the duodenum. Our findings demonstrated that pretreatment with the combination of CG and CLX during 5-FU-induced intestinal mucositis was more effective in reversing histopathological effects than treatment with CLX alone, a commercially available nonsteroidal anti-inflammatory drug that acts as a selective inhibitor of COX-2. Short et al. [54] suggested that low doses of CLX can be used therapeutically for the protection of the intestinal barrier in patients with inflammatory bowel disorders, because of its ability to reduce COX-2 expression. Javle et al. [55] found that the combination of irinotecan (CPT-11) and CLX resulted in antitumor effects, with improvement in irinotecan-induced diarrhea and lethality. Furthermore, CG (90 mg/kg) alone or in combination with CLX was able to decrease 5-FU-induced COX-2 and IL- $1 \beta$ immunostaining in the duodenum. It is known that IL-1 $\beta$ is produced by macrophages, monocytes, and glial cells. This proinflammatory cytokine induces the expression of inflammatory mediators, such as COX-2 with subsequent release of prostaglandins, and the onset of primary tissue damage and progression [56-58]. The gene expression and tissue levels of IL-1 $\beta$ are correlated with intestinal mucosal injury induced by chemotherapy [59].

The study and use of natural polysaccharides in inflammatory bowel diseases, especially mucositis, is a current reality and future promise for the development of effective drugs in the treatment of 5-FU-induced intestinal mucositis. The present study has however a limitation. As intestinal inflammation is a complex process involving multiple mechanisms of activation and maintenance of the inflammatory process, the hypothetical model of action of CG on 5-FU-induced intestinal mucositis in mice proposed using the results of the present study (Figure 7) may be inadequate. Further studies are needed to elucidate the other possible mechanisms of CG action in intestinal mucositis. 


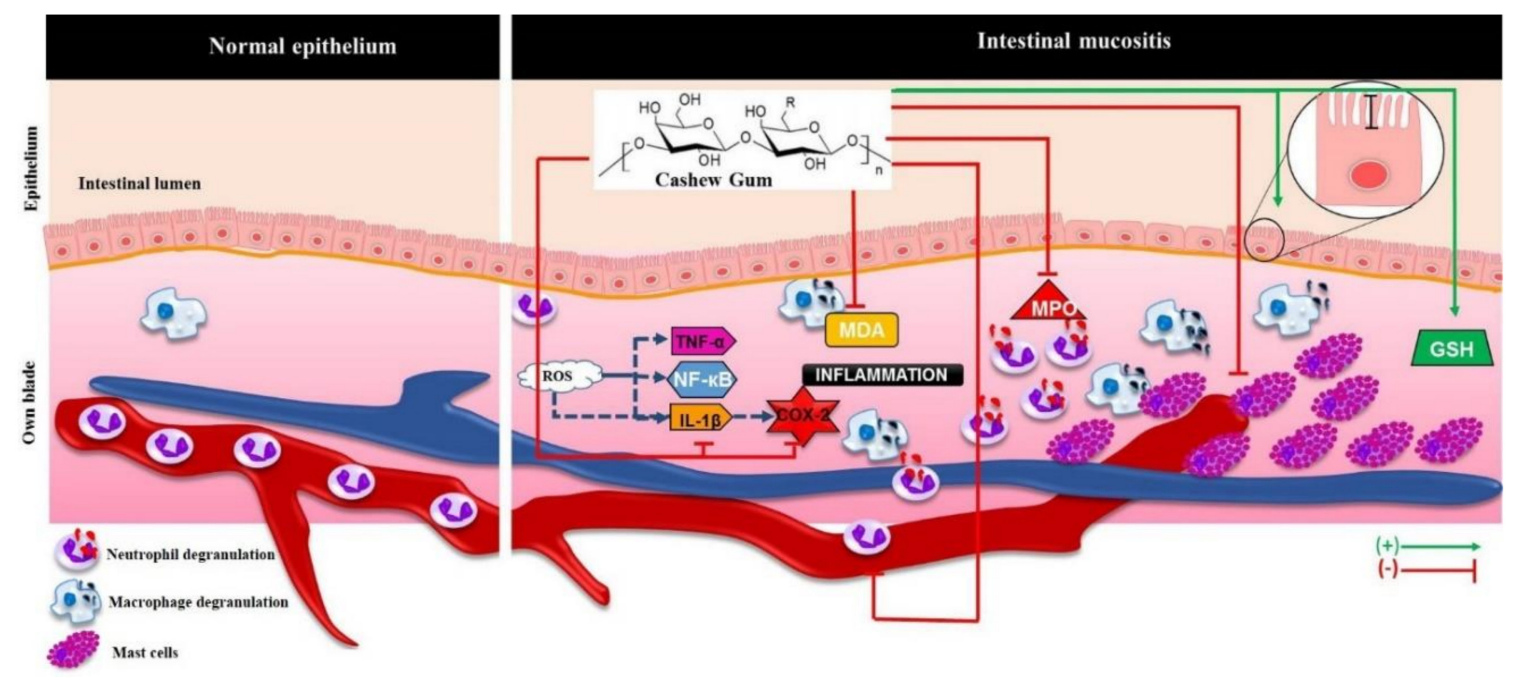

Figure 7. Hypothetical model of action of CG in intestinal mucositis induced by 5-FU. CG prevented the 5-FU-induced injury intestinal through inhibition of MDA formation, neutrophil recruitment (decreasing MPO levels), mast cells activation and IL-1 $\beta$ and COX-2 immunostaining marker and inhibited leucopenia. CG also stimulate villus enlargement and increase levels of GSH, an antioxidant. ROS: Reactive Oxygen Species; TNF- $\alpha$ : Tumor Necrosis Factor-alpha; NF-кB: transcription factor nuclear kappa b; IL-1ß: Interleukin 1 beta; COX-2: Cyclooxygenase 2; MDA: Malondialdehyde; MPO: Myeloperoxidase; GSH: Reduced glutathione. Arrows green (stimulate / increase), red arrows (inhibit).

\section{Materials and Methods}

\subsection{Animals}

The animals were obtained from the Department of Surgery of the Federal University of Ceara (UFC) were used. The male Swiss mice (25-30 g) were housed in polypropylene cages, lined with wood, in a controlled environment with a temperature of $23 \pm 2{ }^{\circ} \mathrm{C}$, in a cycle of $12 \mathrm{~h} \mathrm{light} / 12 \mathrm{~h}$ dark, with free access to water and standard feed. The procedures and experimental protocols were approved by the Ethics Committee on Animal Use ( $n^{\circ}$ 208/16) from the Federal University of Piaui (CEUA/UFPI).

\subsection{Drugs and Plant Materials}

Two drug drugs were used for mucositis induction and treatment, respectively: 5-FU (FauldFluor ${ }^{\circledR}$, Libbs, Sao Paulo, Brazil) celecoxib (CLX-Celebra ${ }^{\circledR}$, Pfizer, Sao Paulo, Brazil). Raw samples of CG were collected in 2013 by the Biotechnology and Biodiversity Center Research-BIOTEC, Parnaíba, Brazil, from the trunk of native cashew trees (A. occidentale L.) in Ilha Grande de Santa Isabel, Piauí, Brazil (Latitude, decimal degrees S-2.8242; Longitude, decimal degrees W-41.7331). The tree was identified and a voucher specimen, voucher number 52, was deposited at the HDELTA herbarium (Federal University of Piauí, Parnaíba, Piauí, Brazil).

\subsection{Extraction and Purification of Cashew Gum}

The CG was purified with sodium salt, as previously described [60]. Bark free nodules were selected and dissolved at a final concentration of $5 \%(w / v)$ in distilled water. The $\mathrm{pH}$ of the solution was adjusted to approximately 7.0. The clear solution was successively filtered through sintered glass and the heteropolysaccharide was precipitated with ethanol [61,62].

\subsection{Induction of Experimental Intestinal Mucositis}

The experimental intestinal mucositis model in Swiss Mice was induced as described by Soares et al. [39]. The 5-FU (450 mg/kg) was given intraperitoneally (i.p) in a single dose on the first day of the experimental protocol. Three days of treatment with CG were performed. The mice 
were pretreated daily with oral CG $(30,60,90 \mathrm{mg} / \mathrm{kg}), 1 \mathrm{~h}$ before the injection of 5 - FU, after then the same oral doses were performed once a day. After four days of treatment, the animals were euthanized by ketamine $(270 \mathrm{mg} / \mathrm{kg})$ and xylazine $(15 \mathrm{mg} / \mathrm{kg})$ and the intestinal samples were collected. The body weight of mice was measured daily before the treatment administered to confirm the experimental model of intestinal mucositis induced by 5 -FU. In this study, the mice was randomly allocated in seven groups $(n=6)$ : Saline ( $\mathrm{NaCl} 0.9 \%), 5-\mathrm{FU}(5-\mathrm{FU}+\mathrm{NaCl} 0.9 \%), \mathrm{CG} 30(5-\mathrm{FU}+\mathrm{CG} 30 \mathrm{mg} / \mathrm{kg})$, CG 60 (5-FU + CG 60 mg/kg), CG 90 (5-FU + CG $90 \mathrm{mg} / \mathrm{kg})$, CLX (5-FU + celecoxib $7.5 \mathrm{mg} / \mathrm{kg}$, i.p), CLX + CG 90 (5-FU + celecoxib $7.5 \mathrm{mg} / \mathrm{kg}$, i.p + CG $90 \mathrm{mg} / \mathrm{kg}$ ). To investigate the participation of COX-2 on the effects of treatment with CG during intestinal mucositis induced by 5-FU, COX-2 was blocked by celecoxib in an independent experiment. The mice were treated with celecoxib and CG 90 in combination or alone for three days.

\subsection{Histopathological and Morphometric Analysis}

After euthanasia, duodenum samples were obtained and fixed in $10 \%$ formaldehyde for performing the histopathological and morphometric analysis $[63,64]$. These samples were embedded in paraffin, sectioned at $4 \mu \mathrm{m}$ and stained with hematoxylin and eosin (H\&E). A blinded and randomized histopathological analysis was performed by an experienced histopathologist to assess the severity of mucositis using a scores system [65], the tissues were ranging from 0 (absence of lesion/normal histological findings) to 3 (maximum lesion degree), indicating shortened villi with vacuolized cells, necrosis of crypts, intense infiltration of inflammatory cells, vacuolization and edema in the mucosal layer and muscular layer with edema, vacuolization and neutrophil infiltrate. The effective concentration of CG in the treatment of mucositis was determined following the histological analysis.

\subsection{Leukocyte Count}

Mice were anesthetized with a combination of anesthetics (xylazine $10 \mathrm{~m} / \mathrm{kg}$ and ketamine $80 \mathrm{mg} / \mathrm{kg}$ ) and, a peripheral blood sample was collected from the ocular artery, and was diluted in the liquid of Turk at a ratio of $20 \mu \mathrm{L}$ of blood to $380 \mu \mathrm{L}$ of solution. The total leukocytes were counted using a Neubauer chamber [66], and the results were expressed as a total number of leukocytes per mm3 of blood.

\subsection{Dosage of Malondialdehyde (MDA)}

The MDA is a product of lipid peroxidation frequently used as a marker of oxidative stress. Briefly, the intestinal samples were homogenized $(10 \%)$ with potassium phosphate buffer $(1.15 \%)$. Then, were added phosphoric acid (1\%) and thiobarbituric acid $(0.6 \%)$ to the homogenates and incubated at $\left(100{ }^{\circ} \mathrm{C}\right.$, for $45 \mathrm{~min}$ ) followed by the addition of $1.5 \mathrm{~mL} n$-butanol. The supernatant was obtained and measured after centrifugation (5000 rpm, for $10 \mathrm{~min}$ ). The results were expressed as nMol of MDA/mg of tissue by $535 \mathrm{~nm}$ absorbance measure $[67,68]$.

\subsection{Concentration of Glutathione (GSH)}

The concentration of GSH in the duodenal samples was performed according to the method described by Sedlak and Lindsay [69]. The levels of nonprotein sulfhydryl groups (NPSH) were determined from 50 to $100 \mathrm{mg}$ of the intestinal mucosa of each animal. The tissues were homogenized in $1 \mathrm{~mL}$ of $0.02 \mathrm{M}$ EDTA for each sample. Aliquots of $100 \mu \mathrm{L}$ of the homogenate were mixed with $80 \mu \mathrm{L}$ of distilled water and $20 \mu \mathrm{L}$ of $50 \%$ trichloroacetic acid (TCA) for precipitation of proteins. The tubes were centrifuged for $15 \mathrm{~min}$ at $3000 \mathrm{rpm}$ at $4{ }^{\circ} \mathrm{C}$. A total of $100 \mu \mathrm{L}$ of the supernatant was added to $200 \mu \mathrm{L}$ of $0.4 \mathrm{M}$ Tris buffer (pH 8.9) and $5 \mu \mathrm{L}$ of $0.01 \mathrm{M}$ 5,5-dithiobis-(2-nitrobenzoic acid) (DTNB, Sigma Aldrich, St. Louis, Missouri, USA). The mixture was then homogenate for 3 min and the absorbance was read at $412 \mathrm{~nm}$. Results were expressed as micrograms of NPSH groups per milliliter of homogenate $(\mu \mathrm{g} / \mathrm{mL})$. 


\subsection{Myeloperoxidase Assay (MPO)}

MPO activity was determined by the technique described by Bradley et al [70]. Briefly, the duodenum segments (50-100 mg) were homogenized in $1 \mathrm{~mL}$ of potassium buffer containing $0.5 \%$ hexadecyltrimethylammonium bromide (HTAB), then centrifuged ( $4000 \mathrm{rpm}, 7 \mathrm{~min}, 4^{\circ} \mathrm{C}$ ). The MPO activity was analyzed by measuring the absorbance at $450 \mathrm{~nm}$ using diisocyanate dihydrochloride and $1 \%$ hydrogen peroxide in the resuspended pellet. The results were recorded as MPO units per mg tissue.

\subsection{Mast Cell Analysis}

The paraffin blocks with duodenum samples were processed for toluidine blue staining to identified mast cells, according to Michalany [71]. The slides were deparaffinized with xylene, incubated for $3 \mathrm{~min}$ with toluidine blue solution ( $1 \mathrm{~g}$ of toluidine blue dissolved in $70 \%$ ethanol), washed three times in distilled water, dehydrated, and mounted. The total number of mast cells were counted manually, considering four specimens per group and ten fields per slide. The results were expressed as the mean of 10 fields in each group.

\subsection{Immunohistochemistry for the Detection of COX-2 and IL-1 $\beta$}

Duodenal sections were deparaffinized with oven insertion $\left(60^{\circ} \mathrm{C}\right)$ and three cycles of xylol immersion for $5 \mathrm{~min}$ each. Then, the sections were rehydrated in decreasing alcohol concentrations (100, 90,80 and $70 \%$ ). The histological sections were then washed with distilled water for $10 \mathrm{~min}$ and the antigenic recovery in citrate buffer ( $\mathrm{pH} 7.0, \mathrm{DAKO}{ }^{\circledR}$, Sao Paulo, Brazil) was carried out for $20 \mathrm{~min}$ in the water bath $\left(95^{\circ} \mathrm{C}\right)$. The slides were then washed with phosphate-buffered saline solution (PBS) for $5 \mathrm{~min}$ at room temperature. Following, endogenous peroxidase blockade with $3 \%$ hydrogen peroxide solution $\left(\mathrm{H}_{2} \mathrm{O}_{2}\right)$ was performed for $30 \mathrm{~min}$. The sections were then incubated overnight with goat anti-COX-2 primary antibody (SantaCruz ${ }^{\circledR}$, Dallas, TX, USA), and rabbit anti-IL-1 $\beta$ (SantaCruz ${ }^{\circledR}$, Dallas, TX, USA) diluted in antibody diluent (1:100) for $60 \mathrm{~min}$, respectively. After the slides were washed with PBS and incubated with rabbit IgG (GBI Labs ${ }^{\circledR}$, Bothell, WA, USA) secondary antibody diluted (1:400) for $30 \mathrm{~min}$. For revelation, the sections were incubated with the streptavidin conjugated peroxidase complex (ABC complex) for $30 \mathrm{~min}$ and chromogen $3,3^{\prime}$ diaminobenzidine peroxide, DAB (DAKO ${ }^{\circledR}$, Sao Paulo, Brazil), followed by counterstaining with hematoxylin $\left(\mathrm{DAKO}^{\circledR}\right.$, Sao Paulo, Brazil), for $10 \mathrm{~min}$. Negative controls were processed simultaneously as described above, with the primary antibody being replaced for antibody diluent. The procedures were performed in an automated manner using Autostainer Plus (DAKO ${ }^{\circledR}$, Sao Paulo, Brazil). To assess COX-2 immunostaining, quantification was performed by immunolabelled cells with the aid of Image J software. For IL-1 $\beta$ immunostaining images, quantification was performed by measuring the \% immunolabelled area with the aid of Adobe Photoshop 10. All images were captured with the aid of an optical microscope to the image acquisition system (LEICA, Wetzlar, HE, Germany ).

\subsection{Statistical Analysis}

Quantitative results were expressed as mean \pm standard error of the mean (SEM) and the qualitative data (histological scores) were pointed scores and expressed by the median \pm minimum and maximum. The results with a parametric distribution were analyzed by Analysis of Variance (ANOVA) followed by post hoc test Tuckey through the program GraphPad Prism version 6.0 (GraphPad Software Inc., La Jolla, CA, USA). The data obtained from non-parametric distribution were analyzed using Kruskal-Wallis test followed by Dunn's (multiple comparisons). Values of $p$-value $<0.05$ were considered statistically significant. 


\section{Conclusions}

In summary, CG decreased inflammation, oxidative stress, and intestinal injury induced by 5-FU in the duodenum. The effects of CG were found to be related to COX-2 pathway. The concomitant administration of CG and CLX completely reverted COX-2 and IL-1 $\beta$ immunostaining markers and intestinal injury induced by 5-FU. Thus, we suggest that CG has potential application in the development of novel drugs against intestinal mucositis due to antineoplastic agents. Additionally, we recommend further studies to elucidate the molecular mechanisms related to the effects of GC under pro-inflammatory cytokines expression as well as other possible mechanisms of action involved in the protective effect of CG on chemotherapy-induced intestinal mucositis.

Author Contributions: J.A.L.M., L.K.M.S., J.A.R., A.P.F.F., and G.S.C. conceived and designed the experiments; J.A.L.M., J.E.F.B., D.S.M., P.V.S.P., D.V.S.C., R.R.S., C.N.C.L., A.G.S., R.F.C.L., and D.A.S. performed the experiments; J.A.L.M., D.S.M., D.V.S.C., G.A.C.B., J.V.R.M. and G.S.C. analyzed the data; J.A.L.M., R.R.S., D.V.S.C. and G.S.C. wrote the paper.

Acknowledgments: This research was supported by Conselho Nacional de Desenvolvimento Científico e Tecnológico-CNPq, Coordenação de Aperfeiçoamento de Pessoal de Nivel Superior-CAPES, Fundação Cearense de Apoio ao Desenvolvimento Científico e Tecnológico-FUNCAP. We thank Microscopy and Image Processing Core (NEMPI) at Federal University of Ceará.

Conflicts of Interest: The authors declare no conflict of interest.

\section{References}

1. Kumar, V.; Abbas, A.K.; Aster, J.C. Robbins Basic Pathology E-Book, 9th ed.; Elsevier Health Sciences: Rio de Janeiro, Brazil, 2013.

2. Ferreira, J.E.V.; de Figueiredo, A.F.; Barbosa, J.P.; Pinheiro, J.C. Chemometric study on molecules with anticancer properties. In Chemometrics in Practical Applications; IntechOpen: London, UK, 2012; pp. $185-186$.

3. Organization, W.H. Cancer. Available online: http://www.who.int/cancer/en/ (accessed on 17 August 2018).

4. Chang, C.-T.; Ho, T.-Y.; Lin, H.; Liang, J.-A.; Huang, H.-C.; Li, C.-C.; Lo, H.-Y.; Wu, S.-L.; Huang, Y.-F.; Hsiang, C.-Y. 5-Fluorouracil induced intestinal mucositis via nuclear factor- $\kappa \mathrm{B}$ activation by transcriptomic analysis and in vivo bioluminescence imaging. PLoS ONE 2012, 7, e31808. [CrossRef]

5. Udofot, O.; Affram, K.; Bridg'ette Israel, E.A. Cytotoxicity of 5-fluorouracil-loaded pH-sensitive liposomal nanoparticles in colorectal cancer cell lines. Integr. Cancer Sci. Ther. 2015, 2, 245-252. [CrossRef] [PubMed]

6. Wilhelm, M.; Mueller, L.; Miller, M.C.; Link, K.; Holdenrieder, S.; Bertsch, T.; Kunzmann, V.; Stoetzer, O.J.; Suttmann, I.; Braess, J. Prospective, multicenter study of 5-fluorouracil therapeutic drug monitoring in metastatic colorectal cancer treated in routine clinical practice. Clin. Colorectal Cancer 2016, 15, 381-388. [CrossRef] [PubMed]

7. Kawashima, R.; Fujimaki, M.; Ikenoue, Y.; Danjo, K.; Koizumi, W.; Ichikawa, T. Influence of an elemental diet on 5-fluorouracil-induced morphological changes in the mouse salivary gland and colon. Support. Care Cancer 2016, 24, 1609-1616. [CrossRef] [PubMed]

8. Kawashima, R.; Kawakami, F.; Maekawa, T.; Yamamoto, H.; Koizumi, W.; Ichikawa, T. Elemental diet moderates 5-fluorouracil-induced gastrointestinal mucositis through mucus barrier alteration. Cancer Chemother. Pharmacol. 2015, 76, 269-277. [CrossRef]

9. Kobuchi, S.; Ito, Y.; Sakaeda, T. Population Pharmacokinetic-Pharmacodynamic Modeling of 5-Fluorouracil for Toxicities in Rats. Eur. J. Drug Metab. Pharmacokinet. 2017, 42, 707-718. [CrossRef]

10. Peterson, D.; Bensadoun, R.-J.; Roila, F.; Group, E.G.W. Management of oral and gastrointestinal mucositis: ESMO Clinical Practice Guidelines. Ann. Oncol. 2011, 22, 78-84. [CrossRef]

11. Kim, H.J.; Kim, J.H.; Moon, W.; Park, J.; Park, S.J.; Am Song, G.; Han, S.H.; Lee, J.H. Rebamipide attenuates 5-fluorouracil-induced small intestinal mucositis in a mouse model. Biol. Pharm. Bull. 2015, 38, 179-183. [CrossRef]

12. Ofori-Kwakye, K.; Amekyeh, H.; El-Duah, M.; Kipo, S.L. Mechanical and tablet coating properties of cashew tree (Anacardium occidentale l) gum-based films. Asian J. Pharm. Clin. Res. 2012, 5, 62-68.

13. Olusola, A.; Toluwalope, G.; Olutayo, O. Carboxymethylation of Anacardium occidentale L. exudate gum: Synthesis and characterization. Sch. Acad. J. Pharm. 2014, 3, 213-216. 
14. Schirato, G.V.; Monteiro, F.M.F.; Silva, F.d.O.; Luís, d.L.F.J.; Leão, A.M.d.A.C.; Porto, A.L.F. O polissacarídeo do Anacardium occidentale L. na fase inflamatória do processo cicatricial de lesões cutâneas. Ciência Rural 2006, 36, 149-154. [CrossRef]

15. Kumar, A.; Moin, A.; Ahmed, A.; Shivakumar, H.G. Cashew gum a versatile hydrophyllic polymer: A review. Curr. Drug Ther. 2012, 7, 2-12. [CrossRef]

16. Quelemes, P.V.; Araruna, F.B.; de Faria, B.E.; Kuckelhaus, S.A.; da Silva, D.A.; Mendonça, R.Z.; Eiras, C.; dos S Soares, M.J.; Leite, J.R.S. Development and antibacterial activity of cashew gum-based silver nanoparticles. Int. J. Mol. Sci. 2013, 14, 4969-4981. [CrossRef]

17. Araújo, T.S.; Costa, D.S.; Sousa, N.A.; Souza, L.K.; de Araújo, S.; Oliveira, A.P.; Sousa, F.B.M.; Silva, D.A.; Barbosa, A.L.; Leite, J.R.S. Antidiarrheal activity of cashew GUM, a complex heteropolysaccharide extracted from exudate of Anacardium occidentale L. in rodents. J. Ethnopharmacol. 2015, 174, 299-307. [CrossRef] [PubMed]

18. AlRashdi, A.S.; Salama, S.M.; Alkiyumi, S.S.; Abdulla, M.A.; Hadi, A.H.A.; Abdelwahab, S.I.; Taha, M.M.; Hussiani, J.; Asykin, N. Mechanisms of gastroprotective effects of ethanolic leaf extract of Jasminum sambac against $\mathrm{HCl} /$ ethanol-induced gastric mucosal injury in rats. Evid.Based Complement. Altern. Med. 2012, 2012, 786426. [CrossRef]

19. Bonacorsi, C.; Da Fonseca, L.M.; Raddi, M.S.G.; Kitagawa, R.R.; Vilegas, W. Comparison of Brazilian plants used to treat gastritis on the oxidative burst of Helicobacter pylori-stimulated neutrophil. Evid. Based Complement. Altern. Med. 2013, 2013, 851621. [CrossRef] [PubMed]

20. Reddy, S.C.; Shetty, B.V.; Rao, G.M. Oral Ingestion of Spondias pinnata Bark Extract Trim Down Severity of Small Intestinal Mucositis in Etoposide Treated Rats. Cancer Sci. Ther. 2015, 7, 030-033. [CrossRef]

21. Chikezie, P.C. Sodium metabisulfite-induced polymerization of sickle cell hemoglobin incubated in the extracts of three medicinal plants (Anacardium occidentale, Psidium guajava, and Terminalia catappa). Pharmacogn. Mag. 2011, 7, 126-132. [CrossRef]

22. Okpashi, V.E.; Bayim, B.P.-R.; Obi-Abang, M. Comparative effects of some medicinal plants: Anacardium occidentale, Eucalyptus globulus, Psidium guajava, and Xylopia aethiopica extracts in alloxan-induced diabetic male Wistar albino rats. Biochem. Res. Int. 2014, 2014. [CrossRef]

23. Jaiswal, Y.; Tatke, P.; Gabhe, S.; Vaidya, A. Antidiabetic activity of extracts of Anacardium occidentale Linn. leaves on n-streptozotocin diabetic rats. J. Tradit. Complement. Med. 2017, 7, 421-427. [CrossRef]

24. Souza, N.C.; de Oliveira, J.M.; Morrone, M.d.S.; Albanus, R.D.O.; Amarante, M.d.S.M.; Camillo, C.d.S.; Langassner, S.M.Z.; Gelain, D.P.; Moreira, J.C.F.; Dalmolin, R.J.S. Antioxidant and anti-inflammatory properties of Anacardium occidentale leaf extract. Evid. Based Complement. Altern. Med. 2017, 2017, 2787308. [CrossRef] [PubMed]

25. Silva, J.G.d.; Souza, I.A.; Higino, J.S.; Siqueira-Junior, J.P.; Pereira, J.V.; Pereira, M.d.S.V. Atividade antimicrobiana do extrato de Anacardium occidentale Linn. em amostras multiresistentes de Staphylococcus aureus. Rev. Bras. Farmacogn. 2007, 17, 572-577. [CrossRef]

26. Tchikaya, F.O.; Bantsielé, G.B.; Kouakou-Siransy, G.; Datté, J.Y.; Datté, P.; Zirihi, N.G.; Offoumou, M.A. Anacardium occidentale Linn.(Anacardiaceae) stem bark extract induces hypotensive and cardio-inhibitory effects in experimental animal models. Afr. J. Tradit. Complement. Altern. Med. 2011, 8, 452-461. [CrossRef]

27. Cardoso Palheta, I.; Caldeira Tavares-Martins, A.C.; Araujo Lucas, F.C.; Goncalves Jardim, M.A. Ethnobotanical study of medicinal plants in urban home gardens in the city of Abaetetuba, Pará state, Brazil. Boletín Latinoamericano y del Caribe de Plantas Medicinales y Aromáticas 2017, 16, 206-262.

28. Vasconcelos, M.d.S.; Rochette, N.F.G.; de Oliveira, M.L.M.; Nunes-Pinheiro, D.C.S.; Tomé, A.R.; Maia de Sousa, F.Y.; Pinheiro, F.G.M.; Moura, C.F.H.; Miranda, M.R.A.; Mota, E.F. Anti-inflammatory and wound healing potential of cashew apple juice (Anacardium occidentale L.) in mice. Exp. Biol. Med. 2015, 240, 1648-1655. [CrossRef]

29. Yeung, C.-Y.; Chan, W.-T.; Jiang, C.-B.; Cheng, M.-L.; Liu, C.-Y.; Chang, S.-W.; Chiau, J.-S.C.; Lee, H.-C. Amelioration of chemotherapy-induced intestinal mucositis by orally administered probiotics in a mouse model. PLoS ONE 2015, 10, e0138746. [CrossRef]

30. Carvalho, R.D.; Breyner, N.; Menezes-Garcia, Z.; Rodrigues, N.M.; Lemos, L.; Maioli, T.U.; Souza, D.G.; Carmona, D.; Faria, A.M.; Langella, P. Secretion of biologically active pancreatitis-associated protein I (PAP) by genetically modified dairy Lactococcus lactis NZ9000 in the prevention of intestinal mucositis. Microb. Cell Factories 2017, 16, 27. [CrossRef] 
31. Li, Y.; Liu, M.; Zuo, Z.; Liu, J.; Yu, X.; Guan, Y.; Zhan, R.; Han, Q.; Zhang, J.; Zhou, R. TLR9 Regulates the NF-kB-NLRP3-IL-1 $\beta$ Pathway Negatively in Salmonella-Induced NKG2D-Mediated Intestinal Inflammation. J. Immunol. 2017, 199, 761-773. [CrossRef]

32. Gerhard, D.; Sousa, F.J.D.S.S.; Andraus, R.A.C.; Pardo, P.E.; Nai, G.A.; Neto, H.B.; Messora, M.R.; Maia, L.P. Probiotic therapy reduces inflammation and improves intestinal morphology in rats with induced oral mucositis. Braz. Oral Res. 2017, 31, 1-11. [CrossRef]

33. De Araújo, A.A.; Borba, P.B.; de Souza, F.H.D.; Nogueira, A.C.; Saldanha, T.S.; Araújo, T.E.F.; Silva, A.I.; de Araújo Júnior, R.F. In a methotrexate-induced model of intestinal mucositis, olmesartan reduced inflammation and induced enteropathy characterized by severe diarrhea, weight loss, and reduced sucrose activity. Biol. Pharm. Bull. 2015, 38, 746-752. [CrossRef]

34. De Barros, P.A.V.; Andrade, M.E.R.; de Vasconcelos Generoso, S.; Miranda, S.E.M.; dos Reis, D.C.; Leocádio, P.C.L.; e Souza, É.L.d.S.; dos Santos Martins, F.; da Gama, M.A.S.; Cassali, G.D. Conjugated linoleic acid prevents damage caused by intestinal mucositis induced by 5 -fluorouracil in an experimental model. Biomed. Pharmacother. 2018, 103, 1567-1576. [CrossRef] [PubMed]

35. Al-Asmari, A.K.; Khan, A.Q.; Al-Asmari, S.A.; Al-Rawi, A.; Al-Omani, S. Alleviation of 5-fluorouracil-induced intestinal mucositis in rats by vitamin E via targeting oxidative stress and inflammatory markers. J. Complement. Integr. Med. 2016, 13, 377-385. [CrossRef] [PubMed]

36. Han, X.; Wu, Z.; Di, J.; Pan, Y.; Zhang, H.; Du, Y.; Cheng, Z.; Jin, Z.; Wang, Z.; Zheng, Q. CXCL9 attenuated chemotherapy-induced intestinal mucositis by inhibiting proliferation and reducing apoptosis. Biomed. Pharmacother. 2011, 65, 547-554. [CrossRef]

37. Zhang, S.; Liu, Y.; Xiang, D.; Yang, J.; Liu, D.; Ren, X.; Zhang, C. Assessment of dose-response relationship of 5-fluorouracil to murine intestinal injury. Biomed. Pharmacother. 2018, 106, 910-916. [CrossRef] [PubMed]

38. Kumar, S.; Aninat, C.; Michaux, G.; Morel, F. Anticancer drug 5-fluorouracil induces reproductive and developmental defects in Caenorhabditis elegans. Reprod. Toxicol. 2010, 29, 415-420. [CrossRef] [PubMed]

39. Soares, P.M.; Mota, J.M.S.; Gomes, A.S.; Oliveira, R.B.; Assreuy, A.M.S.; Brito, G.A.C.; Santos, A.A.; Ribeiro, R.A.; Souza, M.H. Gastrointestinal dysmotility in 5-fluorouracil-induced intestinal mucositis outlasts inflammatory process resolution. Cancer Chemother. Pharmacol. 2008, 63, 91-98. [CrossRef]

40. Quaresma, M.P. Lactobacillus spp. e Bifidobacterium sp. Attenuate Experimental Intestinal Mucositis Induced by 5-Fluorouracil in Mice; Federal University of Ceará: Fortaleza, Brazil, 2016.

41. Sonis, S.T. A biological approach to mucositis. J. Support. Oncol. 2004, 2, 21-32.

42. Guabiraba, R.; Besnard, A.; Menezes, G.; Secher, T.; Jabir, M.; Amaral, S.; Braun, H.; Lima-Junior, R.C.; Ribeiro, R.; Cunha, F. IL-33 targeting attenuates intestinal mucositis and enhances effective tumor chemotherapy in mice. Mucosal Immunol. 2014, 7, 1079-1093. [CrossRef]

43. Bastos, C.C.C.; de Ávila, P.H.M.; dos Santos Filho, E.X.; de Ávila, R.I.; Batista, A.C.; Fonseca, S.G.; Lima, E.M.; Marreto, R.N.; de Mendonca, E.F.; Valadares, M.C. Use of Bidens pilosa L.(Asteraceae) and Curcuma longa L.(Zingiberaceae) to treat intestinal mucositis in mice: Toxico-pharmacological evaluations. Toxicol. Rep. 2016, 3, 279-287. [CrossRef] [PubMed]

44. Justino, P.F.; Melo, L.F.; Nogueira, A.F.; Costa, J.V.; Silva, L.M.; Santos, C.M.; Mendes, W.O.; Costa, M.R.; Franco, A.X.; Lima, A.A.; et al. Treatment with Saccharomyces boulardii reduces the inflammation and dysfunction of the gastrointestinal tract in 5-fluorouracil-induced intestinal mucositis in mice. Br. J. Nutr. 2014, 111, 1611-1621. [CrossRef] [PubMed]

45. De Ávila, P.H.M.; de Ávila, R.I.; dos Santos Filho, E.X.; Bastos, C.C.C.; Batista, A.C.; Mendonca, E.F.; Serpa, R.C.; Marreto, R.N.; da Cruz, A.F.; Lima, E.M. Mucoadhesive formulation of Bidens pilosa L.(Asteraceae) reduces intestinal injury from 5-fluorouracil-induced mucositis in mice. Toxicol. Rep. 2015, 2, 563-573. [CrossRef]

46. Al-Asmari, A.; Al-Zahrani, A.; Khan, A.; Al-Shahrani, H.; Ali Al Amri, M. Taurine ameliorates 5-flourouracil-induced intestinal mucositis, hepatorenal and reproductive organ damage in Wistar rats: A biochemical and histological study. Hum. Exp. Toxicol. 2016, 35, 10-20. [CrossRef] [PubMed]

47. Heber, D. Oxidative Stress Markers and Inflammation: The Role of Spices and Herbs. Nutr. Today 2014, 49, S4-S5. [CrossRef]

48. Nogueira, L.T.; Costa, D.V.; Gomes, A.S.; Martins, C.S.; Silva, A.M.; Coelho-Aguiar, J.M.; Castelucci, P.; Lima-Júnior, R.C.; Leitão, R.F.; Moura-Neto, V.; et al. The involvement of mast cells in the irinotecan-induced enteric neurons loss and reactive gliosis. J. Neuroinflamm. 2017, 14, 79. [CrossRef] 
49. Hamilton, M.J.; Frei, S.M.; Stevens, R.L. The multifaceted mast cell in inflammatory bowel disease. Inflamm. Bowel Dis. 2014, 20, 2364-2378. [CrossRef] [PubMed]

50. De Winter, B.Y.; van den Wijngaard, R.M.; de Jonge, W.J. Intestinal mast cells in gut inflammation and motility disturbances. Biochim. Biophys. Acta Mol. Basis Dis. 2012, 1822, 66-73. [CrossRef]

51. Theoharides, T.C.; Alysandratos, K.-D.; Angelidou, A.; Delivanis, D.-A.; Sismanopoulos, N.; Zhang, B.; Asadi, S.; Vasiadi, M.; Weng, Z.; Miniati, A.; et al. Mast cells and inflammation. Biochim. Biophys. Acta Mol. Basis Dis. 2012, 1822, 21-33. [CrossRef]

52. Ramsay, D.B.; Stephen, S.; Borum, M.; Voltaggio, L.; Doman, D.B. Mast cells in gastrointestinal disease. Gastroenterol. Hepatol. 2010, 6, 772-777.

53. Bischoff, S.C. Mast cells in gastrointestinal disorders. Eur. J. Pharmacol. 2016, 778, 139-145. [CrossRef]

54. Short, S.S.; Wang, J.; Castle, S.L.; Fernandez, G.E.; Smiley, N.; Zobel, M.; Pontarelli, E.M.; Papillon, S.C.; Grishin, A.V.; Ford, H.R. Low doses of celecoxib attenuate gut barrier failure during experimental peritonitis. Lab. Investig. 2013, 93, 1265-1275. [CrossRef] [PubMed]

55. Javle, M.M.; Cao, S.; Durrani, F.A.; Pendyala, L.; Lawrence, D.D.; Smith, P.F.; Creaven, P.J.; Noel, D.C.; Iyer, R.V.; Rustum, Y.M. Celecoxib and mucosal protection: Translation from an animal model to a phase I clinical trial of celecoxib, irinotecan, and 5-fluorouracil. Clin. Cancer Res. 2007, 13, 965-971. [CrossRef] [PubMed]

56. Verri Jr, W.A.; Cunha, T.M.; Parada, C.A.; Poole, S.; Cunha, F.Q.; Ferreira, S.H. Hypernociceptive role of cytokines and chemokines: Targets for analgesic drug development? Pharmacol. Ther. 2006, 112, 116-138. [CrossRef] [PubMed]

57. Al-Azri, A.R.; Gibson, R.J.; Bowen, J.M.; Stringer, A.M.; Keefe, D.M.; Logan, R.M. Involvement of matrix metalloproteinases (MMP-3 and MMP-9) in the pathogenesis of irinotecan-induced oral mucositis. J. Oral Pathol. Med. 2015, 44, 459-467. [CrossRef]

58. Ribeiro, R.A.; Wanderley, C.W.; Wong, D.V.; Mota, J.M.S.; Leite, C.A.; Souza, M.H.; Cunha, F.Q.; Lima-Junior, R.C. Irinotecan-and 5-fluorouracil-induced intestinal mucositis: Insights into pathogenesis and therapeutic perspectives. Cancer Chemother. Pharmacol. 2016, 78, 881-893. [CrossRef]

59. Al-Dasooqi, N.; Sonis, S.T.; Bowen, J.M.; Bateman, E.; Blijlevens, N.; Gibson, R.J.; Logan, R.M.; Nair, R.G.; Stringer, A.M.; Yazbeck, R.; et al. Emerging evidence on the pathobiology of mucositis. Support. Care Cancer 2013, 21, 2075-2083. [CrossRef]

60. De Paula, R.; Santana, S.; Rodrigues, J. Composition and rheological properties of Albizia lebbeck gum exudate. Carbohydr. Polym. 2001, 44, 133-139. [CrossRef]

61. Silva, D.A.; Feitosa, J.P.; Maciel, J.S.; Paula, H.C.; de Paula, R.C. Characterization of crosslinked cashew gum derivatives. Carbohydr. Polym. 2006, 66, 16-26. [CrossRef]

62. Da Silva, D.A.; Feitosa, J.P.; Paula, H.C.; de Paula, R.C. Synthesis and characterization of cashew gum/acrylic acid nanoparticles. Mater. Sci. Eng. C 2009, 29, 437-441. [CrossRef]

63. Soares, P.M.; Mota, J.M.S.; Souza, E.P.; Justino, P.F.; Franco, A.X.; Cunha, F.Q.; Ribeiro, R.A.; Souza, M.H. Inflammatory intestinal damage induced by 5-fluorouracil requires IL-4. Cytokine 2013, 61, 46-49. [CrossRef]

64. Dos Santos Filho, E.X.; Ávila, P.H.M.; Bastos, C.C.C.; Batista, A.C.; Naves, L.N.; Marreto, R.N.; Lima, E.M.; Mendonca, E.F.; Valadares, M.C. Curcuminoids from Curcuma longaL. reduced intestinal mucositis induced by 5 -fluorouracil in mice: Bioadhesive, proliferative, anti-inflammatory and antioxidant effects. Toxicol. Rep. 2016, 3, 55-62. [CrossRef]

65. MacPherson, B.; Pfeiffer, C. Experimental production of diffuse colitis in rats. Digestion 1978, 17, $135-150$. [CrossRef] [PubMed]

66. Moura, R.; Wada, C.; Purchio, A.; Almeida, T. Studies of the Figurative Elements of Blood, 3rd ed.; Atheneu: São Paulo, Brazil, 1998.

67. Bradford, M.M. A rapid and sensitive method for the quantitation of microgram quantities of protein utilizing the principle of protein-dye binding. Anal. Biochem. 1976, 72, 248-254. [CrossRef]

68. Ohkawa, H.; Ohishi, N.; Yagi, K. Assay for lipid peroxides in animal tissues by thiobarbituric acid reaction. Anal. Biochem. 1979, 95, 351-358. [CrossRef]

69. Sedlak, J.; Lindsay, R.H. Estimation of total, protein-bound, and nonprotein sulfhydryl groups in tissue with Ellman's reagent. Anal. Biochem. 1968, 25, 192-205. [CrossRef] 
70. Bradley, P.P.; Priebat, D.A.; Christensen, R.D.; Rothstein, G. Measurement of cutaneous inflammation: Estimation of neutrophil content with an enzyme marker. J. Investig. Dermatol. 1982, 78, 206-209. [CrossRef] [PubMed]

71. Michalany, J. Histological Technique Pathological Anatomy: With Instructions for the Surgeon, Nurse, Cytotechnician, 3rd ed.; Michalany: São Paulo, Brazil, 2008. 